[Agr. Biol. Chem. Yol. 36, No. 2, p. 198 206, 1972]

\title{
Neutral Proteinases I and II of Aspergillus sojae
}

\author{
Isolation in Homogeneous $\mathrm{Form}^{\dagger}$
}

\author{
By Hiroshi Sekine \\ Noda Institute for Scientific Research, \\ Noda-shi, Chiba-ken, Japan \\ Received July 3, 1971
}

\begin{abstract}
Two neutral proteinases (I and II) of Aspergillus sojae were isolated from wheat bran culture by DEAE-cellulose chromatography. Neutral proteinase I was purified by sequential chromatography on columns of CM-cellulose, Sephadex G-100 and hydroxylapatite. Neutral proteinase II was purified by chromatographies on DEAE-Sephadex A-50, hydroxylapatite and Sephadex G-100. Crystalline preparation was obtained from neutral proteinase II, but not from neutral proteinase $I$. The purified preparation of each enzyme was found to be homogeneous on sedimentation analysis, disc electrophoresis and disc electrofocusing. A notable difference in specific activity was observed between the two neutral proteinases, i.e., 1,050 and 35 proteinase units per $\mathrm{mg}$ of enzyme protein for neutral proteinases I and II, respectively. Determination of the ultraviolet absorption spectra indicated that the $E_{1 \mathrm{~m}}^{1 \%}$ at $280 \mathrm{~m} \mu$ of neutral proteinases $I$ and II were 16.7 and 9.0 , respectively. The molecular weights of neutral proteinases I and II were estimated to be 41,700 and 19,800 , respectively, by gel filtration, and their isoelectric points were found to be $\mathrm{pH} 4.7$ and $\mathrm{pH} 4.2$, respectively, by disc electrofocusing.
\end{abstract}

Aspergillus sojae widely used in the soy sauce brewing in Japan is known to produce an alkaline proteinase, two neutral proteinases" and an acid proteinase. The minor production of a few other proteinases by this mold is also suggested." As to the enzymatic characteristics or the role in soy sauce brewing of these enzymes, only a little information is available except for the alkaline proteinase which was isolated in a homogeneous state $^{31}$ and characterized in detail ${ }^{\sim \sim 6)}$ by Hayashi et al. Recent experiment of Nakadai et al. revealed an important role of at least six kinds of exo-peptidases in the liberation of low molecular peptides and amino acids in the digestion of soybean protein by the proteolytic enzymes of $A$. sojae or $A$. oryzae. ${ }^{7}$ In a pre-

\footnotetext{
$t$ Presented at the Annual Meeting of the Agricultural Chemical Society of Japan, Tokyo, April 1, 1971 .
}

vious paper, ${ }^{8)}$ neutral proteinases I and II were suggested to have a significant contribution comparable to that of alkaline proteinase which is a major component of the proteolytic enzymes produced by $A$. sojae, in the digestion of protein component (mainly soybean protein) in soy sauce brewing.

It is of significance, therefore, to elucidate all over the features of neutral proteinases of this mold and to investigate the mode of soybean protein digestion by these enzymes in detail using the highly purified preparations.

The present paper describes the purification procedure of Aspergillus sojae neutral proteinases I and II starting from wheat bran culture.

\section{MATERIALS AND METHODS}

Assay of proteolytic activity. Proteolytic activity was determined as previously described.91 Because phosphate ions were found to inhibit neutral prote- 
inase 1 , the phosphate buffer was replaced by the Tris buffer. The reacion mixture containing $1 \mathrm{ml}$ each of enzyme solution, distilled water and $1.5 \%$ Hammarsten milk casein in $0.1 \mathrm{M}$ Tris-HCl buffer ( $\mathrm{pH} \mathrm{7.3)} \mathrm{was} \mathrm{incubated} \mathrm{at} 30^{\circ} \mathrm{C}$ for $10 \mathrm{~min}$ and the reaction was stopped by the addition of $3 \mathrm{ml}$ of 0.44 M trichloroacetic acid (TCA) solution, followed by filtration. One milliliter of the filtrate was mixed with $4 \mathrm{ml}$ of $0.5 \mathrm{M}$ sodium carbonate solution and then $1 \mathrm{ml}$ of phenol reagent was added to it. The optical density of the color developed was measured at $660 \mathrm{~m} \varphi$. One proteinase unit (PU) was defined as the amount of enzyme which liberates $1 \mu \mathrm{g}$ tyrosine in the reaction mixture for one minute under the assay conditions and the specific activity was expressed as units per mg enzyme protein.

Determination of protein concentration. Protein concentration of neutral proteinases I and II was determined spectrophotometrically assuming that the $E_{1 \mathrm{~cm}}^{1 \%}$ at $280 \mathrm{~m} \mu$ of the proteins in $50 \mathrm{~mm}$ Tris-HCl buffer $(\mathrm{pH} 7.3)$ were 16.7 and 9.0 , respectively, which were estimated by the dry weight measurement of the purified enzyme preparations.

Ultracentrifugation. Sedimentation analysis was carried out at $20^{\circ} \mathrm{C}$ with a Hitachi Model UCA-1A analytical ultracentrifuge.

Disc electrophoresis. Polyacrylamide gel disc electrophoresis was carried out at pHs 9.4 (Tris-glycine buffer), ${ }^{10,11)} 8.0$ (Tris-diethylbarbiturate buffer), ${ }^{12}$, 6.6

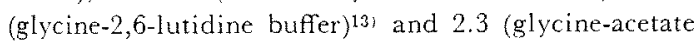
buffer).14 The protein dissolved in $20{ }^{\circ}$ (w/v) sucrose solution was applied directly on top of the 7.5\% separation gel and run at the constant current of 3 $\mathrm{mA}$ per gel for $60 \mathrm{~min}$ in a cold room. After electrophoresis, the gels were stained with amino black 10 $B$ and destained with $7 \%$ acetic acid solution.

Disc electrofocusing.* Isoelectric focusing on polyacrylamide gel was carried out using carrier ampholite ( $\mathrm{pH} \quad 3 \sim 10$ Ampholine, LKB-produkter A. B.) according to the method of Catsimpoolas. ${ }^{15}$ ) The protein mixed into the central vicinity of gel (about one-fourth length of the total gel) was run at the constant voltage of $70 \mathrm{~V}$ for $150 \mathrm{~min}$ in a cold room.

* Detailed procedure for the operation is described in 1. Koshiyama, Agr. Biol. Chem., 36, 62 (1972), Presented at the Annual Meeting of the Agricultural Chemical Society of Japan, Tokyo, April 2, 1971.
For the proteinase assay and $\mathrm{pH}$ determination, the gel was sliced into about $2 \mathrm{~mm}$ width and extracted with $2 \mathrm{ml}$ of water. The gel for staining was steeped in $120^{\circ}$ TCA solution for 3 days to remove the ampholite from gel and then stained with amino black $10 \mathrm{~B}$.

Estimation of molecular weight by gel filtration. The estimation of the molecular weight was performed according to the method of Andrews ${ }^{16,17}$ with a Sephadex G-100 column $(2 \times 60 \mathrm{~cm})$, which was equilibrated previously with $50 \mathrm{mM}$ Tris-HCl-2 $\mathrm{mm}$ calcium acetate buffer ( $\mathrm{pH} 7.5$ ) containing $0.05 \mathrm{M}$ sodium chloride. Elution was performed with the same buffer in a cold room at a flow rate of $12 \mathrm{ml} / \mathrm{hr}$ and $4 \mathrm{ml}$ fractions were collected. Marker proteins used as standard were as follows: cytochrome c (molecular weight, $M=12,400$, from horse heart, type III, Sigma), ribonuclease A ( $M=13,700$, bovine pancreas, Sigma), Aspergillus sojae alkaline proteinase $(M=22,600, \mathrm{kindl} y$ supplied from Dr. K. Hayashi), pepsin ( $M=35,400$, N.B.C.) and ovo-albumin ( $M=45,000$, N.B.C.). Results are presented in terms of $\mathrm{Kd}$, the parameter defined by Gelotte. ${ }^{18}$. The void volume of the column was measured using blue dextran.

All the operation for enzyme purification were carried out in a cold room.

\section{RESULTS AND DISCUSSION}

\section{Preparation of the crude enzymes}

Six kilograms of wheat bran culture of Aspergillus sojae strain $\mathrm{KS}$ was extracted overnight with 20 liters of water under the presence of $50 \mathrm{ml}$ of toluene. About 16 liters of the clear solution was obtained by the filtration using "Hyflosupercel." To this clear solution was added solid ammonium sulfate to give 458 saturation and the resulting precipitate was removed by filtration. To the filtrate was added solid ammonium sulfate to give $80 \circ$ saturation. The resulting precipitate was separated by filtration, dissolved in about $500 \mathrm{ml}$ of $5 \mathrm{mM}$ Tris-HCl-2 mM calcium acetate buffer ( $\mathrm{pH} 7.5$ ) containing $0.05 \mathrm{M}$ sodium chloride and dialyzed against the same buffer. The dialyzed enzyme solution was applied on a column of DEAE-cellulose. After washing out the alkaline proteinase with the same 
buffer, the neutral proteinase I and then the neutral proteinase II were eluted with a linear gradient increase in sodium chloride concentration. A typical elution pattern is shown in Fig. 1.

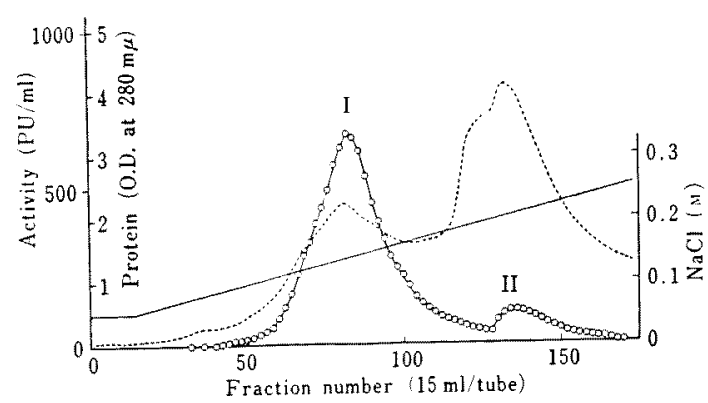

FIG. 1. Elution Profile of Aspergillus sojae Neutral Proteinases in DEAE-cellulose Column Chromatography.

Column size: $3 \times 75 \mathrm{~cm}$, flow rate: $45 \mathrm{ml} / \mathrm{hr}$.

Reservoir consisted of 2 liters of $5 \mathrm{mM}$ Tris$\mathrm{HCl}-2 \mathrm{mM}$ calcium acetate buffer $(\mathrm{pH} 7.5)$ containing $0.4 \mathrm{M} \mathrm{NaCl}$. Mixing chamber contained 2 liters of the same buffer containing $0.05 \mathrm{M} \mathrm{NaCl}$.

-..... Protein, $-\mathrm{O}$ Activity, $-\mathrm{NaCl}$.

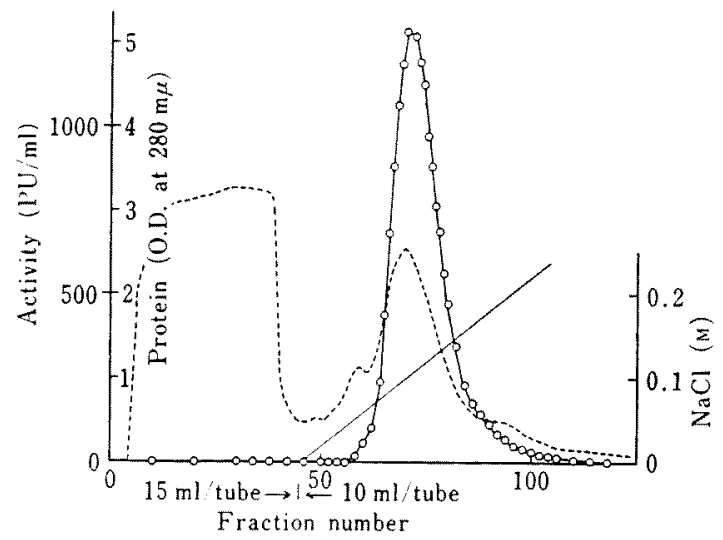

FIG. 2. Column Chromatogram of Neutral Proteinase $\mathrm{I}$ on CM-cellulose.

Column size: $2 \times 30 \mathrm{~cm}$, flow rate: $30 \mathrm{ml} / \mathrm{hr}$. Reservoir consisted of $500 \mathrm{ml}$ of $20 \mathrm{~mm}$ lactate$2 \mathrm{mM}$ calcium acetate buffer $(\mathrm{pH} 4.2$ ) containing $0.3 \mathrm{M} \mathrm{NaCl}$ and mixing chamber contained $500 \mathrm{ml}$ of the same buffer without $\mathrm{NaCl}$.

-...- Protein, O-O Activity, — $\mathrm{NaCl}$.

\section{Purification of neutral proteinase I}

The crude neutral proteinase I fraction from the previous step was dialyzed against $20 \mathrm{mM}$ lactate-2 $\mathrm{mM}$ calcium acetate buffer ( $\mathrm{pH} 4.2$ ).

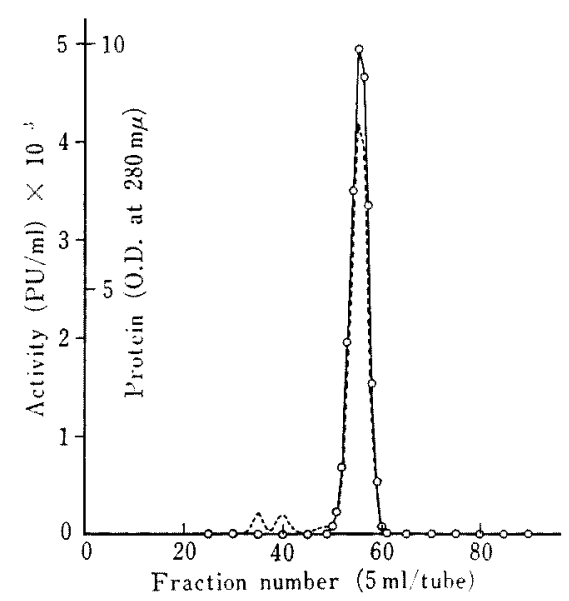

FIG. 3. Gel-filtration of Neutral Proteinase $I$ on Sephadex G-100.

-..-- Protein, 0 - Activity.

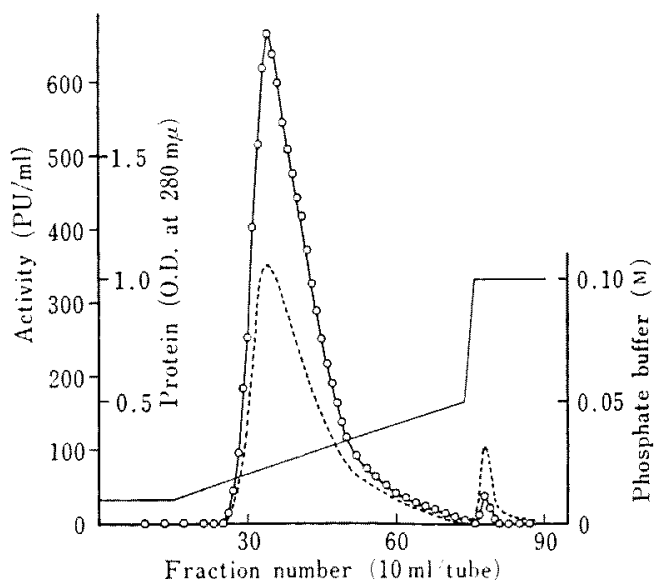

FIG. 4. Column Chromatogram of Neutral Proteinase I on Hydroxylapatite.

Column size: $3 \times 5 \mathrm{~cm}$, flow rate: $50 \mathrm{ml} / \mathrm{hr}$. Reservoir consisted of $500 \mathrm{ml}$ of $0.077 \mathrm{M}$ phosphate buffer $(\mathrm{pH} 7.0)$ and mixing chamber contained $500 \mathrm{ml}$ of $0.01 \mathrm{M}$ phosphate buffer $(\mathrm{pH} 7.0)$. ----- Protein, O-O Activity, — Phosphate buffer. 
The dialyzed solution was loaded on a column of CM-cellulose equilibrated with the same buffer. The active fractions, which were eluted with a linear gradient in sodium chloride concentration shown in Fig. 2, were combined and mixed with two volumes of cold acetone. The resulting precipitate was collected by centrifugation and dissolved in a minimal quantity of $5 \mathrm{~mm}$ Tris-HCl-2 $\mathrm{mm}$ calcium acetate buffer ( $\mathrm{pH}$ 7.5) containing $0.05 \mathrm{M}$ sodium chloride and applied on a column of Sephadex G-100 $(2.64 \times 95 \mathrm{~cm})$ previously equilibrated with the same buffer. Elution was performed with the same buffer by upward flow system at a flow rate of 10 $\mathrm{ml} / \mathrm{hr}$ (Fig. 3). The combined active fractions were further dialyzed against $10 \mathrm{~mm}$ phosphate buffer ( $\mathrm{pH}$ 7.0) and applied on a column of hydroxylapatite (Bio-Gel HT, Bio-Rad Laboratories) previously equilibrated with the same buffer. Final preparation of neutral proteinase I was eluted with a linear gradient increase of phosphate ion concentration as shown in Fig. 4.

\section{Purification of neutral proteinase II}

The crude neutral proteinase II fraction from the DEAE-cellulose chromatography was

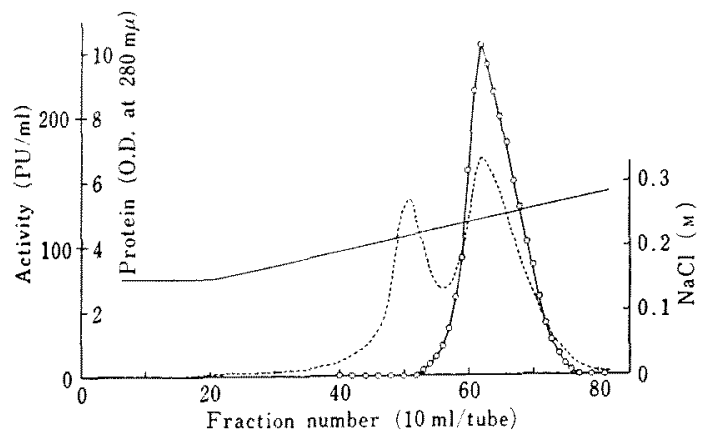

FIG. 3. Column Chromatogram of Neutral Proteinase II on DEAE-Sephadex A-50.

Column size: $2 \times 50 \mathrm{~cm}$, flow rate: $30 \mathrm{ml} / \mathrm{hr}$.

Reservoir consisted of $500 \mathrm{ml}$ of $5 \mathrm{mM}$ TrisHCl.2 $\mathrm{mM}$ calcium acetate buffer ( $\mathrm{pH} 7.5$ ) containing $0.30 \mathrm{M} \mathrm{NaCl}$ and mixing chamber contained 500 $\mathrm{ml}$ of the same buffer containing $0.15 \mathrm{M} \mathrm{NaCl}$.

..... Protein, O-O Activity, - $\mathrm{NaCl}$.

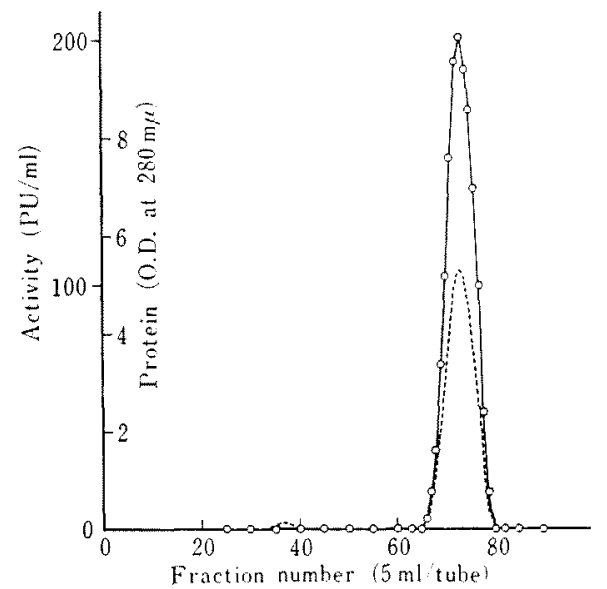

FIG. 6. Gel-filtration of Neutral Proteinase II on Sephadex G-100

....- Protein, O-O Activity.

dialyzed against $5 \mathrm{~mm}$ Tris-HCl-2 $\mathrm{mm}$ calcium acetate buffer $(\mathrm{pH} 7.5$ ) containing $0.15 \mathrm{M}$ sodium chloride. The dialyzed solution was applied on a column of DEAE-Sephadex A-50 and eluted with a linear gradient increase in sodium chloride concentration as shown in Fig. 5. The combined active fraction, after dialysis against $4 \mathrm{~mm}$ phosphate buffer $(\mathrm{pH}$ 7.0 ), was loaded on a column of hydroxylapatite $(3 \times 5 \mathrm{~cm})$ previously equilibrated with the same buffer. To active fraction which passed unadsorbed through the column, two volumes of cold acetone was added. The resulting precipitate was collected by centrifugation and dissolved in a minimal quantity of $5 \mathrm{mM}$ Tris-HCl-2 $\mathrm{mm}$ calcium acetate buffer (pH 7.5) containing $0.05 \mathrm{M}$ sodium chloride and then loaded on a column of Sephadex G-100 $(2.64 \times 95 \mathrm{~cm})$ equilibrated with the same buffer. Final preparation of neutral proteinase II was obtained by upward flow system with the same buffer at a flow rate of $10 \mathrm{ml} / \mathrm{hr}$ (Fig. 6).

\section{Summary of purification procedure}

The over-all sequence of the purification procedures is summarized in Table I. A 
Table I. Purification of Neutral Proteinases of Aspergillus sojae

\begin{tabular}{|c|c|c|c|c|}
\hline Procedure & $\begin{array}{l}\text { Volume } \\
\text { (ml) }\end{array}$ & $\begin{array}{l}\text { Total activity } \\
\text { (PU) }\end{array}$ & $\begin{array}{c}\text { Specific activity } \\
(\mathrm{PU} / \mathrm{O} . \mathrm{D} \text { at } 280 \mathrm{~m} \mu)\end{array}$ & $\begin{array}{l}\text { Yield } \\
(\%)\end{array}$ \\
\hline Crude extract & 16,000 & $\left.950,000^{a}\right)$ & $1.3^{a 1}$ & 100 \\
\hline \multicolumn{5}{|l|}{ Precipitation by $\left(\mathrm{NH}_{4}\right)_{2} \mathrm{SO}_{4}$} \\
\hline Dialyzate & 800 & $380,000^{a 1}$ & $19.7 a 1$ & 40 \\
\hline \multicolumn{5}{|l|}{ DEAE-cellulose chromatography } \\
\hline Crude neutral proteinase I & 540 & 238,000 & 186 & 25 \\
\hline \multirow[t]{2}{*}{ Crude neutral proteinase II } & 380 & 27,600 & 14.8 & 2.9 \\
\hline & & \multicolumn{3}{|c|}{ (PU/mg protein) } \\
\hline Crude neutral proteinase I & 540 & 238,000 & 310 & 100 \\
\hline CM-cellulose chromatography & 250 & 124,000 & 740 & 52.1 \\
\hline \multicolumn{5}{|l|}{ Acetone precipitation } \\
\hline Sephadex G-100 gel-filtration & 45 & 83,000 & 850 & 34.9 \\
\hline \multirow[t]{2}{*}{ Hydroxylapatite chromatography } & 170 & 65,600 & 1,050 & 27.6 \\
\hline & & \multicolumn{3}{|c|}{ (PU/mg protein) } \\
\hline Crude neutral proteinase II & 380 & 27,600 & 13.6 & 100 \\
\hline DE.AE-Sephadex A-50 chromatography & 160 & 13,800 & 20.1 & 50.0 \\
\hline Hydroxylapatite chromatography & 170 & 7,450 & 26.1 & 27.0 \\
\hline \multicolumn{5}{|l|}{ Acetone precipitation } \\
\hline Sephadex G-100 gel-filtration & 50 & 5,900 & 35.0 & 21.4 \\
\hline
\end{tabular}

a) assayed in the presence of potato inhibitor ${ }^{19}$

notable difference in specific activity was observed between the two neutral proteinases. The specific activity of neutral proteinase II is considered to be too low when compared with those of various endo-proteinases reported so far.

\section{Crystallization of enzymes}

The final preparation of neutral proteinase II was dissolved in a small volume of $2 \mathrm{~mm}$ calcium acetate solution (about $20 \mathrm{mg}$ protein/ $\mathrm{ml}$ ). Under gentle agitation chilled acetone was gradually added to it until the solution showed slight cloudiness and the mixture was allowed to stand in a refrigerator. Crystallization of the enzyme began within a few days. Figure 7 shows microphotograph of the crystalline neutral proteinase II. Attempts to crystallize neutral proteinase I using acetone or ammonium sulfate were unsuccessfull.

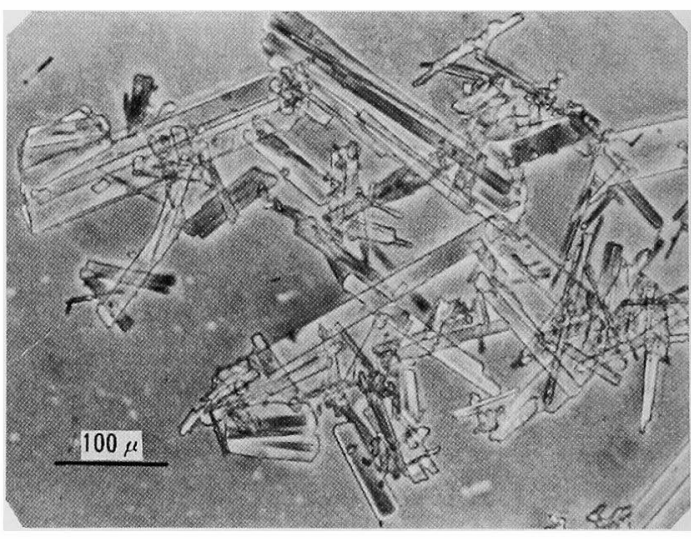

FIG. 7. Crystals of Neutral Proteinase II.

\section{Homogeneity}

Homogeneity of the final enzyme preparations was examined by ultracentrifugal analysis, and both disc electrophoresis and disc electro- 
Neutral proteinase I

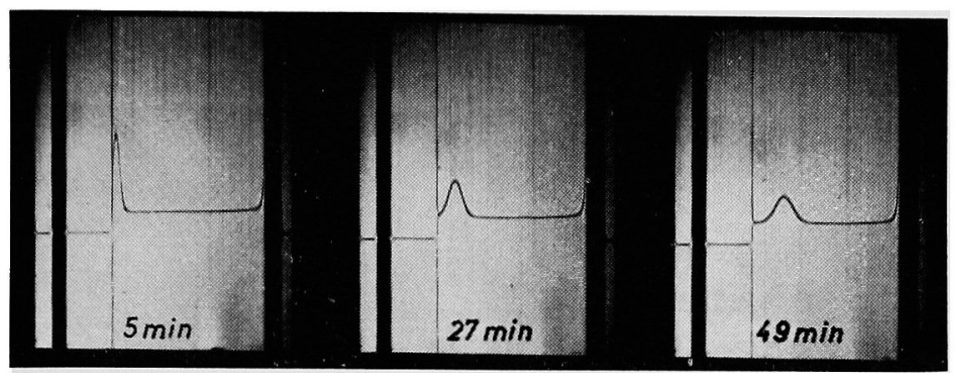

Neutral proteinase II

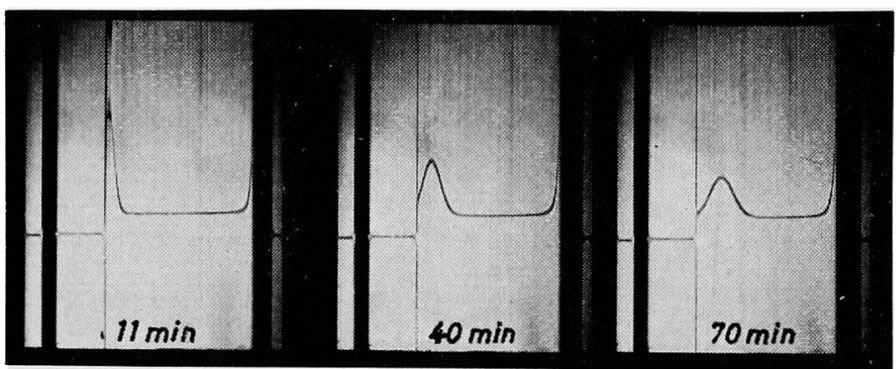

FIG. 8. Sedimentation Patterns of Neutral Proteinases I and II.

The final preparation was dissolved in $5 \mathrm{~mm}$ Tris-HCl-2 $\mathrm{mm}$ calcium acetate buffer $\left(\mathrm{pH} 7.5\right.$ ) containing $0.1 \mathrm{M} \mathrm{NaCl}$ to give the concentration of $0.510^{\circ}$ for neutra! proteinase I and $0.98^{\circ}$ for neutral proteinase II. The photographs were taken at the indicated periods after attainment of full speed (55,430 rpm). Temperature: $20^{\circ} \mathrm{C}$, bar angle: $70^{\circ}$.
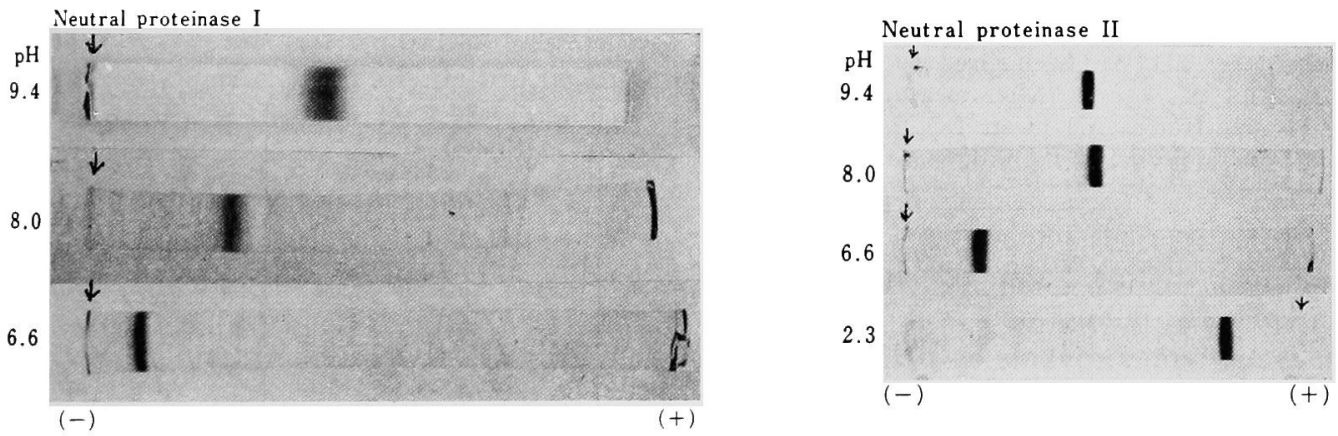

FIG. 9. Polyacrylamide Gel Disc Electrophoresis of Neutral Proteinases I and II.

Arrows indicate the position of sample applied. Neutral proteinase I: $19 \mu \mathrm{g}$, Neutral proteinase II: $16 \mu \mathrm{g}$.

focusing using polyacrylamide gels.

Ultracentrifugal analysis showed that each neutral proteinase was monodispersive (Fig. 8).

Figure 9 shows the results of polyacrylamide gel disc electrophoresis of the final preparations at various $\mathrm{pH}$ values. Though neutral proteinase I was somewhat insufficient in sharpness in the run at high $\mathrm{pH}$ values and, 
(C)

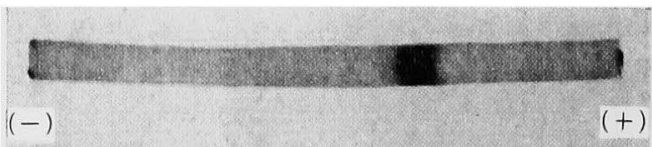

(B)

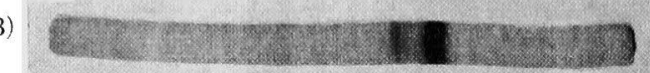

(A)
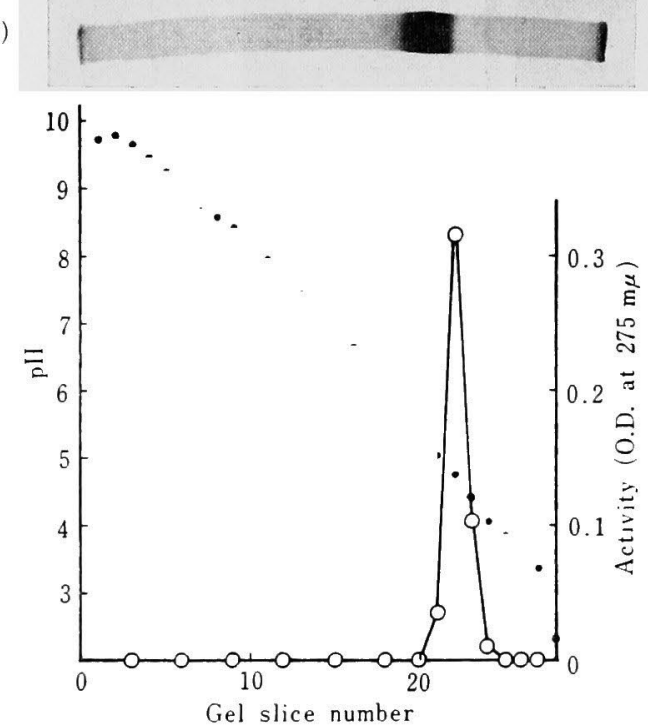

FIG. 10. Isoelectric Focusing in Polyacrylamide Gel Column of Neutral Proteinase I.

Protein applied: about $100 \mu \mathrm{g}$.

(A) and (B): native enzyme, (C): inactivated with $10^{-3} \mathrm{M}$ EDTA. Each sliced gel was extracted with $2 \mathrm{ml}$ of water. After measurement of $\mathrm{pH}$ by Hitachi-Horiba $\mathrm{pH}$ meter $\mathrm{F}-5,1 \mathrm{ml}$ of the extract was subjected to the proteinase assay at $30^{\circ} \mathrm{C}$ for $60 \mathrm{~min}$.

in addition, separated into two bands in the run at $\mathrm{pH} 2.3$, it migrated as a single band without any contaminants at pHs 9.4, 8.0 and 6.6. Neutral proteinase II migrated, on the contrary, as a single, clear band at all $\mathrm{pH}$ values examined.

Figure 10 shows the results of isoelectric focusing in polyacrylamide gel columns of neutral proteinase I. In the usual operation, one proteolytically inactive sub-band was commonly observed, which varied from trace (photograph A) to considerably large amount (photograph B) according to each experimental case even with the same enzyme preparation. The addition of EDTA to the enzyme preparation was effective to prevent the appearance

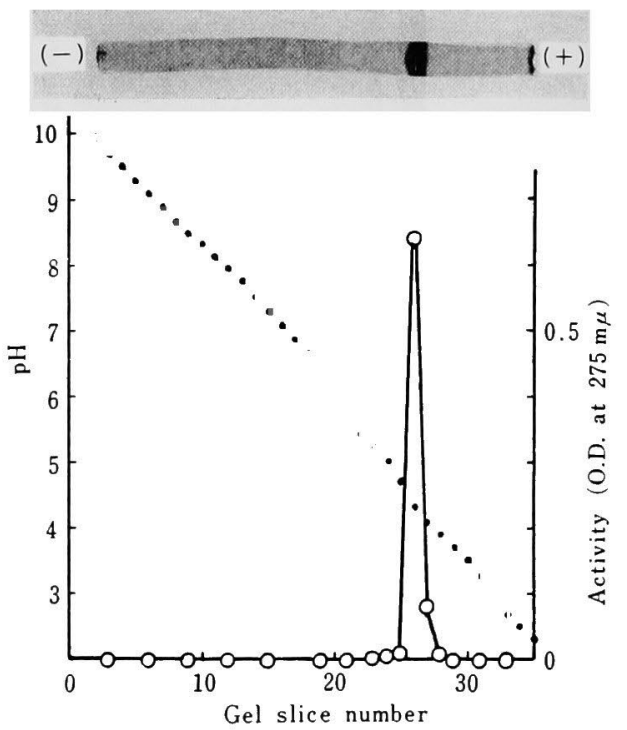

FIG. 11. Isoelectric Focusing in Polyacrylamide Gel Column of Neutral Proteinase II.

Protein applied: about $100 \mu \mathrm{g}$.

Each sliced gel was extracted with $2 \mathrm{ml}$ of water. After measurement of $\mathrm{pH}, \mathrm{lml}$ of the extract was subjected to the proteinase assay at 30 C for $180 \mathrm{~min}$.

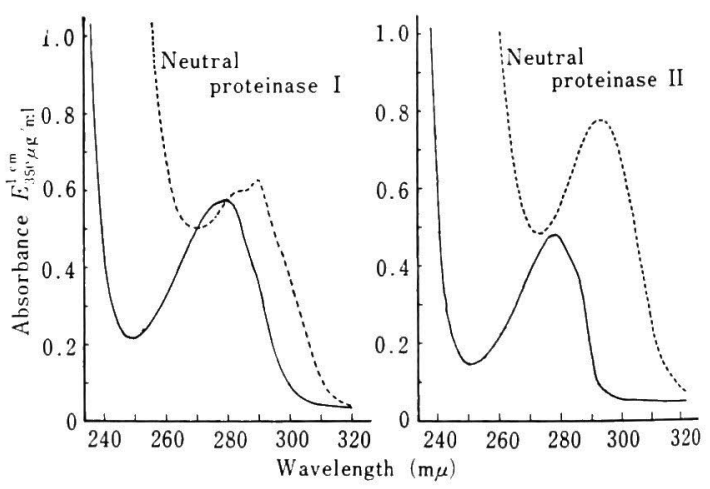

FIG. 12. Ultraviolet Absorption Spectra of Neutral Proteinases I and II.

in $0.1 \mathrm{~N} \mathrm{NaOH}$. 


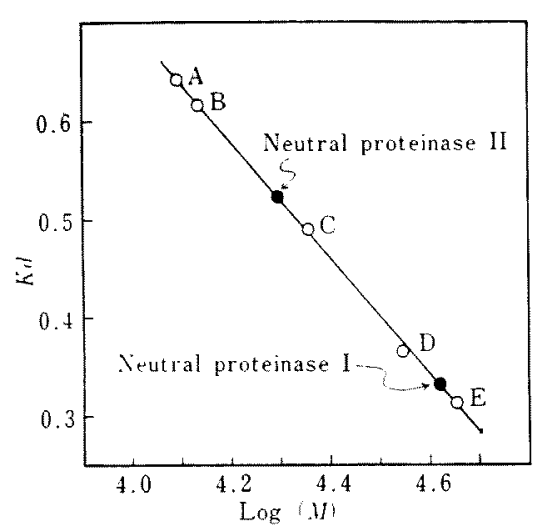

FIG. 13. Estimation of Molecular Weight by Sephadex Gel Filtration.

A: Cytochrome c, B: Ribonuclease, C: Aspergillus sojae alkaline proteinase, D: Pepsin, E: Ovoalbumin. Protein applied: about $5 \mathrm{mg}$.

of the sub-band (photograph $C_{1}$ ). This subband is, therefore, considered to be an artifact produced during the operation of this experiment. The isoelectric point of neutral proteinase I was estimated to be $\mathrm{pH} 4.70 \pm 0.10$ from the data repeated several times. The results of the same experiment with neutral proteinase II are shown in Fig. 11. In this case, contrary to neutral proteinase I, only a single, clear band was reproducibly observed, and the isoelectric point of neutral proteinase II was estimated to be $\mathrm{pH} 4.23 \pm 0.10$.

\section{Ultraviolet absorption spectra}

The ultraviolet absorption spectra of the enzymes are shown in Fig. 12, from which $E_{1 \mathrm{~m}}^{1 \%}$ at $280 \mathrm{~m} \mu$ of neutral proteinases I and II in $50 \mathrm{~mm}$ Tris- $\mathrm{HCl}$ buffer $(\mathrm{pH} \mathrm{7.3)}$ were calculated to be 16.7 and 9.0 , respectively. The ratios of $E_{280} / E_{260}$ of neutral proteinases I and II were also calculated to be 1.72 and 2.24 , respectively.

\section{Molecular weight estimation}

To obtain a rough estimation of the molecular weights of the enzymes, each final preparation was passed through a column of
Sephadex G-100 as described in Materials and Methods, and the elution pattern was compared with those of several marker proteins. Figure 13 shows the results of gel filtration and the molecular weights of neutral proteinases I and II were estimated to be approximately 41,700 and 19,800 , respectively.

In the present paper, the purification procedure of neutral proteinases I and II and some evidence for the homogeneity of the final preparations were described. The detailed experiments on the enzymatic characteristics and physicochemical properties of these enzymes will be presented in the following papers.

Acknowledgement. The author wishes to express his sincere thanks to Prof. K. Arima and Prof. Y. Ikeda for their kind guidance and also to Drs. M. Mogi, N. Iguchi and S. Nasuno for their unfailing support and encouragement. Thanks are also due to Dr. I. Koshiyama for his guidance in the operation of analytical ultracentrifuge and isoelectric focusing, and to Drs. K. Hayashi and N. Saito for their valuable suggestion and discussion.

\section{REFERE $Y$ CES}

1) K. Yamamoto and K. Hayashi, Symposium on Enzyme Chemistry (Japan), 18, 21 (1962).

2) K. Yamamoto, Scientific Report of Noda Shoyu Co., Ltd., No. 8 (1963).

3) K. Hayashi, D. Fukushima and K. Mogi, Agr. Biol. Chem., 31, 1237 (1967).

4) K. Hayashi, D. Fukushima and K. Mogi, ibid, 31, 1171 (1967).

5) K. Hayashi, D. Fukushima and K. Mogi, ibid, 32, 988 (1968).

6) K. Hayashi, M. Terada and K. Mogi, ibid., 34, 627 (1970).

7) T. Nakadai, S. Nasuno and N. Iguchi, in preparation. Presented at the Annual Meeting of the Agricultural Chemical Society of Japan, Tokyo, April 1, 1971.

8) H. Sekine, S. Nasuno and N. Iguchi, Agr. Biol. Chem., 34, 1690 (1970)

9) H. Sekine, S. Nasuno and N. Iguchi, ibid., 33, 1477 (1969). 
10) L. Omstein, Ann. Vew York Acad. Sci., 121, art. 2, 321 (1964).

11) B. J. Davis, ibid., 121, art. 2, 404 (1964).

12) D. E. Williams and R. A. Reisfeld, ibid., 121, art. 2, 373 (1964).

13) H. W. Taber and F. Sherman, ibid., 121, art. 2, 600 (1964).
14) M. Kikutani, Kagaku to Seibutsu, 7, 620 (1969).

15) N. Catsimpoolas, Anal. Biochem., 26, 480 (1968).

16) P. Andrews, Biochem. J., 91, 222 (1964).

17) P. Andrews, ibid., 96, 595 (1965).

18) B. J. Gelotte, J. Chromatog., 3, 330 (1960).

19) K. Matsushima, Nippon Nogeikagaku Kaishi, 33, 116 (1959). 